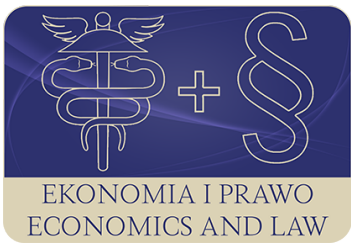

EKONOMIA I PRAWO. ECONOMICS AND LAW

Volume 18, Issue 3, September 2019

p-ISSN 1898-2255, e-ISSN 2392-1625

www.economicsandlaw.pl

EKONOMIA I PRAWO
ECONOMICS AND LAW

ORIGINAL ARTICLE

received 15.07.2018; revised 30.07.2019; accepted 30.09.2019

Citation: Pieloch-Babiarz, A. (2019). Ownership structure, board characteristics and dividend policy: evidence from the Warsaw Stock Exchange. Ekonomia i Prawo. Economics and Law, 18(3): 317-330.

doi:10.12775/EiP.2019.022.

\title{
Ownership structure, board characteristics and dividend policy: evidence from the Warsaw Stock Exchange
}

\author{
ALEKSANDRA PIELOCH-BABIARZ \\ University of Lodz, Faculty of Economics and Sociology, Department of International Finance \\ and Investments, ul. Rewolucji 1905 r. 41, 90 -214 Lodz, Poland \\ ๑aleksandra.pieloch@uni.lodz.pl \\ (D) orcid.org/0000-0001-7885-1284
}

\begin{abstract}
Motivation: The ownership structure is a frequently undertaken research issue on the dividend determinants. However, there are not many scientific studies conducted on the Warsaw Stock Exchange (WSE) which investigate the ownership structure of dividend payers in the context of board characteristics (i.e. board composition, board independence or chairman entrenchment). Therefore, a research gap has been observed in this area and an appropriate study has been conducted.

Aim: The aim of the paper is to investigate the links between the ownership structure of publicly traded companies and the dividend pay-outs in the context of board characteristics.

Results: Empirical research has been conducted on a group of 354 non-financial companies listed on the WSE. The results of the study indicate that in the companies that pay out dividend one can observe a greater share of both the institutional investors and the State Treasury. The board of such companies is bigger, the board members more often hold shares and the chairman occupies the position for a longer time. Moreover, the propensity to pay dividend and dividend amount increase if there is an increase in institutional ownership, board duality and chairman entrenchment.
\end{abstract}


Keywords: dividend pay-out; ownership structure; board composition; board independence; chairman entrenchment

JEL: G11; G18; G35

\section{Introduction}

There are many approaches that attempt to explain why companies pay out dividends. One of them is based on the agency theory, according to which companies transfer a part of earnings to shareholders to reduce agency costs. In this theory, dividends are paid out to signal the good behaviour of board in managing free cash flows (Adjaoud \& Hermassi, 2017, p. 92). As Jensen (1986, p. 247) argues managers could use free cash flows to increase the personal benefits, i.e. perks, incentives, bonuses (Bohdanowicz, 2016, p. 19) and destroy shareholder value. If dividends are paid, the stock market reacts positively because investors receive a signal that managers do not waste free cash flows in unprofitable investment projects. Therefore, dividends mitigate the agency costs resulting from the conflict between managers and shareholders (Grullon et al., 2005, p. 1659). However, some questions arise here. What if the managers are also the owners of the company? Do their goals begin to coincide with the shareholders' goals? Is then the dividend pay-out more often and in what amount? Therefore, there is a research gap which this paper tries to partially fill.

The aim of the paper is to investigate the links between the ownership structure of publicly traded companies and the dividend pay-outs in the context of board characteristics of the companies listed on the Warsaw Stock Exchange (WSE). Such a goal formulation is related to investors' preferences and their search for effective investment opportunities.

Basing on the literature presented in section 2 and taking into consideration contradictory results of the studies conducted on different stock markets, two main research hypotheses have been formulated:

- Hl: There is a negative correlation between a number of managers' votes and dividend pay-out ratio.

- H2: The ownership structure and board characteristics affect the dividend payment in diverse ways.

The second research hypothesis has been operationalized by formulating four auxiliary hypotheses. They are as follows:

- H2a: There is a positive relationship between the institutional ownership and dividend pay-out.

- H2b: There is a positive relationship between the board size and the dividend pay-out.

- H2c: There is a positive relationship between the duality of board members and the dividend pay-out.

- H2d: There is a positive relationship between a number of years of occupying the position by chairman and the dividend pay-out. 
The remainder of this paper is organized as follows. Section 2 contains a short literature review. Section 3 describes the research methodology. Section 4 presents the research results and discusses them. Section 5 highlights the research findings.

\section{Literature review}

There are many studies investigating the links between the ownership structure and dividend pay-outs, but their results are contradictory. Considering the results of research on the ownership concentration, it should be noted that some of them prove that as the ownership concentration increases, an increase in dividend payment is observed. The reason for that is seen in a strong impact of dominant shareholder on decisions made in the company and their power to benefit themselves (Mancinelli \& Ozkan, 2006, p. 256). However, the majority of studies show a negative link between the dominant shareholder and dividend pay-out (Barclay et al., 2009, p. 2423; Bena \& Hanousek, 2008, p. 106; Harada \& Nguyen, 2011, p. 362; Maury \& Pajuste, 2005, pp. 1813$1834)$, which is explained by the use of earnings to improve company performance (Gugler \&Yurtoglu, 2003, p. 731) and - according to the entrenchment hypothesis - extract private benefits by dominant shareholders at the expense of minority shareholders. This situation can occur through the voting per leverage as well as an implementation of private benefits from control, tunneling and self-dealing (Adamska, 2013, p. 175; Baltowski, 2017, p. 27). It should be added that ownership concentration can be differently related to dividend payout depending on minority shareholders' legal power to force a company to pay out dividends. It is observed that in civil-law countries dividends are lower than those in common-law countries (Kowalewski et al., 2008, p. 203; La Porta et al., 2000, p. 3; Moortgat et al., 2017, p. 113).

The literature presents contradictory research results regarding the State Treasury and institutional investors as dominant shareholders. Some authors argue that those investors strive to generate high financial benefits so dividend is paid (Smith et al., 2017, p. 38). Due to great capital involvement the State Treasury and institutional investors can control managers and make decisions about dividend. Therefore, a positive relationship between the institutional ownership and dividend is observed in some studies (Aluchna et al., 2019, p. 227; Short et al., 2002, p. 105). Similar research results are obtained in case of the state ownership (Liljeblom \& Maury, 2016, p. 2414; Nowak et al., 2017, p. 119; Sierpińska-Sawicz, 2014, p. 225). However, in the majority of studies dividend pay-out is negatively correlated with state ownership (Al-Najjar \& Kilincarslan, 2016, p. 135; Ben-Nasr, 2015, p. 665).

According to the literature, in the companies in which managerial ownership increases the dividend is paid out less frequently and in a lower amount (Florackis et al., 2015, p. 783; Short et al., 2002, p. 105). Therefore, reaching the high return on investment in the form of dividend should be possible 
by investing money in the companies in which managerial ownership is low. Most authors show a negative relationship between the managerial ownership and dividend pay-out. It is argued that managers prefer to invest free cash flows rather than pay out dividend (Short et al., 2002, p. 105). In contrast, some authors prove that if managers hold shares their goals start to be consistent with the goals of other shareholders, which results in dividend pay-out (Smith et al., 2017, p. 38). In turn, Florackis at al. (2015, p. 783) show a negative link between the managerial ownership and dividend pay-out only if managers hold relatively few shares. However, this negative relationship turns into a positive one when managerial ownership increases. But not only managerial ownership has an impact on dividend payment. Some studies prove that board characteristics are also very important. Adjaoud \& Hermassi (2017, p. 101) show that the propensity to pay dividend is positively impacted by CEO duality and board size. They argue that large boards allow the inclusion of more diversity, which is good to improve the quality of decision making and acting in the best interest of the shareholders (Adjaoud \& Hermassi, 2017, p. 93). What is more, the chairman entrenchment is crucial. The company is more likely to pay out dividend if the chairman is longer in this position. It confirms that dividend is one of the financial tools that are used by managers to entrench themselves (Schooley \& Baney, 1994, p. 363). Furthermore, the dividend decisions are negatively related to board independence (Mehdi et al., 2017, p. 274) as well as depend on board gender (Wellalage et al., 2014, p. 115). Adams \& Ferreira (2009, p. 291) prove that companies with more female managers have higher cash flows, and in order to reduce free cash flow problems they pay out dividend to the shareholders.

\section{Methods}

The empirical research was conducted on the group of 354 companies listed on the WSE in 2016. The financial institutions and companies with missing data were excluded from the research sample. An investigation was carried out in a few stages.

First, the research variables were chosen. The description of variables was presented in table 1 . The dependent variables included propensity to pay dividend (div) and dividend pay-out ratio (dpr). In turn, the independent variables were divided into three groups, i.e. the variables describing the ownership structure (institution, individual, company, state, ffloat), the variables concerning the characteristics of board of directors (board_size, board_dual, board_votes, board_indep, chairm_year) as well as the control variables (profit, liquid, In_size, tobin_q). Second, the descriptive statistics and t-Student test for two independent samples were used to recognize the statistical significance of average value differences of the research variables for companies paying out and non-paying out dividend. Third, to investigate the strength and direction of relationship between the different variables, the Pearson correlation coefficient was used. Basing on the Pearson correlation matrix, the strongest correlated variables were 
found. Then, the explanatory variables that are most strongly correlated with the others (i.e. these for which the value module of the Pearson correlation coefficient is higher than 0.5) were excluded from the further research. Fourth, the coefficients of logit and Tobit models were estimated to recognize the impact of the ownership structure and board characteristics on the dividend pay-out.

The impact of different determinants on the propensity to pay dividend was investigated using the logistic regression model given by the following formula (Stanisz, 2007, p. 220):

$$
P\left(Y=1 / X_{1}, X_{2}, \ldots, X_{k}\right)=\frac{e^{\beta_{0}+\sum_{i=1}^{k} \beta_{i} X_{i}}}{1+e^{\beta_{0}+\sum_{i=1}^{k} \beta_{i} X_{i}}},
$$

where:

$P\left(Y=1 \mid X_{1}, X_{2}, \ldots, X_{k}\right)$ - conditional probability that the dependent variable div is equal to 1 for the independent variables $X_{i}$;

$\beta_{i}$ - regression coefficients;

$X_{i}$ - independent variables presented in table 1 .

In order to recognize the impact of ownership structure and board characteristics on the amount of dividend pay-out, the Tobit regression model was used. This model was formulated as follows (Kufel, 2009, s. 146):

$$
Y=\left\{\begin{array}{cl}
Y^{*}=\beta_{0}+\sum_{i=1}^{k} \beta_{i} X_{i}+\varepsilon & \text { if } Y^{*}>0 \\
0 & \text { if } Y^{*}=0
\end{array},\right.
$$

where:

$Y$ - dependent variable dpr and the other designations as above.

The study has been carried out using statistical package Statistica 12.5 and Gretl. The data have been collected from the Notoria Serwis database.

\section{Results}

The results of empirical research presented in table 2 show that the ownership structure of non-financial companies listed on the Warsaw Stock Exchange is diverse. The individual investor occurs predominantly (55.1\%), however the institutional investor is also observed very often (54.2\%). Moreover, in 18.6\% of cases another company is the shareholder and in 5.1\% the State Treasury is the owner. When one takes into account the dominant shareholder ${ }^{1}$ it is worth to notice that in $32.8 \%$ of companies the individual investor is the largest shareholder, while in $30.5 \%$ of cases another company holds the majority of shares. In turn, the institutional investor is a dominant shareholder in $12.7 \%$ of companies, and the State Treasury in 3.9\%.

1 The dominant shareholder is defined in this paper as the owner of publicly traded company with the largest number of votes during the general meeting of shareholders. In $15.5 \%$ of studied companies managers are the dominant shareholders. 
Table 3 provides the summary statistics for the dividend paying and non-paying companies. The dividend payers are characterized by a higher average share of institutional investors (15.1\% to 9.1\%). This difference is highly significant. What is more, the dividend paying companies have a higher share of the State Treasury and the lower share of free float. When considering the board characteristics, it is worth to notice that the board of dividend payers is bigger (3.5 members for the dividend payers compared to 2.9 members for non-paying companies), board members more often hold shares $(36.2 \%$ and $25.1 \%$, respectively) which give them relatively more votes at the general meeting of shareholders (11.3\% to $8.0 \%$, respectively). In terms of the chairman entrenchment, the average chairman's seniority in dividend paying companies is longer than in non-paying companies (approx. 6 years to almost 4.5 years). However, the board independence is not significantly different between the paying and non-paying companies. Moreover, the dividend payers are more profitable and liquid, bigger in size and have greater development opportunities than non-paying companies. These differences are statistically significant.

Table 4 provides correlation coefficients for the research variables. One can notice a statistically significant, positive albeit weak relationship between the institutional ownership and both the propensity to pay dividend and the dividend pay-out ratio (correlation coefficient is at 0.190 and 0.209 , respectively). Moreover, the propensity to pay dividend is positively impacted by the state ownership and some board characteristics. The probability of dividend pay-out increases along with an increase in the number of board members, board duality and chairman entrenchment $(0.145,0.106$ and 0.121 , respectively) as well as along with an increase in profitability, liquidity and size of the company $(0.246$, 0.109 and 0.230 , respectively). In turn, the amount of dividend pay-out increases along with an increase in the total assets.

Considering the relationships between the institutional ownership and board characteristics one can notice a negative and weak correlation between the number of votes belonging to institutional investors and managers, as well as between the institutional ownership and board independence (correlation coefficient is at -0.121 and -0.136 , respectively). The achieved results seem to be consistent with the theoretical approach arguing that insiders strive to invest free cash to develop the company rather than to pay out dividend (Short et al., 2002, p. 105). Thus, along with an increase in the managerial ownership fewer institutional investors hold shares. In turn, positive and moderate relationship is observed between the share of individual investors and both the number of votes of managers and the board duality (0.610 and 0.426 , respectively). This is due to the fact that there are many managers among individual investors. Other values of correlation coefficient are presented in table 4. According to table 4, some explanatory variables are strongly correlated with each other. To avoid the collinearity of variables, two of them, i.e. board_vote and board_indep, were excluded from the further research. 
Table 5 presents the estimation results of logit model. Initially, this model contains all explanatory variables and then, these with the highest $\mathrm{p}$-value are subsequently removed and model is re-estimated to achieve the final model in which all variables are statistically significant. The estimated parameters of final model allow to state that the institutional ownership has significant influence on propensity to pay dividend. If the share of votes of institutional investors increases, the likelihood of paying out dividend increases. The dividend is less likely to be paid in case of the companies with larger free float. However, taking into account the board characteristics, one can conclude that the probability of paying out dividend increases if at least one member of board is an owner as well as when the chairman is longer in this position. Moreover, the propensity to pay dividend increases along with the profitability and size of company, which confirms the common opinion that dividend is usually paid out by bigger companies with a good financial standing (Adjaoud \& Hermassi, 2017, p. 90).

The estimation results of Tobit model are presented in table 6. According to the final model, if the share of institutional investor increases, the dividend size increases. In turn, if the free float is larger, the dividend is lower. Analyzing the board characteristics, one can notice that dividend increases if board members are also shareholders of the company, as well as the longer chairman is in this position. Considering the control variables, it should be noted that an increase in the profitability and size of the company results in higher dividend.

\section{Conclusion}

The study provides an additional insight into the relationships between ownership structure and dividend pay-outs in the context of board characteristics.

Referring to the first hypothesis, it should be observed that an increase in the number of managers' votes may have a negative impact on the dividend amount. Results show negative and low correlation which, however, is not statistically significant. Moreover, the empirical findings show that in the companies in which the number of managers' votes is high, the share of the State Treasury, institutional investors and companies is low. This may suggest that reluctance to managerial ownership by institutional investors results from paying out low dividends.

Taking into account four auxiliary hypotheses, it should be noted that all of them were positively verified. In the companies in which institutional ownership is larger both the propensity to pay dividend and the dividend amount are higher, which is consistent with an approach that institutional investors seek dividends. Also, if the board is bigger in size and the number of years of occupying the position by the chairman is longer, the company is more likely to pay out higher dividend. This finding is consistent with the general opinion that big and maturate companies pay out dividend regularly. What is more, it can be assumed that chairman is longer in this position when they pursue shareholders' goals, including these related to the dividend pay-out. In addition, if 
at least one of the board members is an owner, both the propensity to pay dividend and the dividend amount are higher. This may mean that the goals of such a manager start to be consistent with the goals of other shareholders. It can be concluded that the mere presence of managers in the ownership structure (i.e. if they are minority shareholders) increases dividends, but when managers are dominant shareholders and have a real control and impact on the strategic decisions in the company, they prefer to leave a net profit as retained earnings than to transfer it to shareholders. This result suggests extracting private benefits by dominant shareholders at the expense of minority shareholders by tunneling and self-dealing. However, further research is required to confirm this observation.

\section{References}

Adams, R.B., \& Ferreira, D. (2009). Women in the boardroom and their impact on governance and performance. Journal of Financial Economics, 94(2). doi:10.1016/j.jfineco.2008.10.007.

Adamska, A. (2013). Wtasność i kontrola: perspektywa akcjonariuszy spótek publicznych. Warszawa: SGH.

Adjaoud, F., \& Hermassi, N. (2017). The impact of corporate governance mechanisms on the dividend policy of Canadian firms: empirical study. Journal of Business, Accounting and Finance, 11(1).

Al-Najjar, B., \& Kilincarslan, E. (2016). The effect of ownership structure on dividend policy: evidence from Turkey. Corporate Governance, 16(1). doi:10.1108/cg-09-2015-0129.

Aluchna, M., Berent, T., \& Kamiński, T. (2019). Dividend payouts and shareholder structure: evidence from the Warsaw Stock Exchange. Eastern European Economics, 57(3). doi:10.1080/00128775.2019.1568196.

Baltowski, M. (2017). Więcej władzy niż własności: Skarb Państwa jako szczególny inwestor na GPW w Warszawie. Studia Ekonomiczne. Economic Studies, $1(92)$.

Barclay, M., Holderness C., \& Sheehan, D. (2009). Dividends and corporate shareholders. Review of Financial Studies, 22(6). doi:10.1093/rfs/hhn060.

Bena, J., \& Hanousek, J. (2008). Rent extraction by large shareholders: evidence using dividend policy in the Czech Republic. Czech Journal of Economics and Finance (Finance a uver), 58(3-4).

Ben-Nasr, H. (2015). Government ownership and dividend policy: evidence from newly privatised firms. Journal of Business Finance \& Accounting, 42(56). doi:10.1111/jbfa.12115.

Bohdanowicz, L. (2016). Wtasność menedżerska w polskich spótkach publicznych. Łódź: Uniwersytet Łódzki.

Florackis, C., Kanas, A., \& Kostakis, A. (2015). Dividend policy, managerial ownership and debt financing: a non-parametric perspective. European Journal of Operational Research, 241(3). doi:10.1016/j.ejor.2014.08.031. 
Grullon, G., Michaelly, R., Benartzi, S., \& Thaler, R.H. (2005). Dividend changes do not signal changes in future profitability. Journal of Business, 78(5). doi:10.1086/431438.

Gugler, K., \& Yurtoglu, B.B. (2003). Corporate governance and dividend pay-out policy in Germany. European Economic Review, 47(4). doi:10.1016/ S0014-2921(02)00291-X.

Harada, K., \& Nguyen, P. (2011). Ownership concentration and dividend policy in Japan. Managerial Finance, 37(4). doi:10.1108/03074351111115313.

Jensen, M. (1986). Agency costs of free cash flow, corporate finance, and takeovers. American Economic Review, 76(2).

Kowalewski, O., Stetsyuk, I., \& Talavera, O. (2008). Does corporate governance determine dividend payouts in Poland? Post-Communist Economies, 20(2). doi:10.1080/14631370802018973.

Kufel, T. (2009). Ekonometria: rozwiązywanie problemów z wykorzystaniem programu GRETL. Warszawa: PWN.

La Porta, R., Lopez-de-Silanes, F., Shleifer, A., \& Vishny, R. (2000). Investor protection and corporate governance. Journal of Financial Economics, 58(1-2). doi:10.1016/s0304-405x(00)00065-9.

Liljeblom, E., \& Maury, B. (2016). Shareholder protection, ownership, and dividends: Russian evidence. Emerging Markets Finance and Trade, 52(10). doi:10.1080/1540496X.2015.1073991.

Mancinelli, L., \& Ozkan, A. (2006). Ownership structure and dividend policy: evidence from Italian firms. The European Journal of Finance, 12(3). doi:10.1080/13518470500249365.

Maury, C., \& Pajuste, A. (2005). Multiple large shareholders and firm value. Journal of Banking \& Finance, 29(7). doi:10.1016/j.jbankfin.2004.07.002.

Mehdi, M, Sahut, J.M, \& Teulon, F. (2017). Do corporate governance and ownership structure impact dividend policy in emerging market during financial crisis? Journal of Applied Accounting Research, 18(3). doi:10.1108/ JAAR-07-2014-0079.

Moortgat, L., Annaert, J., \& Deloof, M. (2017). Investor protection, taxation and dividend policy: long-run evidence, 1838-2012. Journal of Banking and Finance, 85. doi:10.1016/j.jbankfin.2017.08.013.

Nowak, S., Mosionek-Schweda, M., Mrzygłód, U., \& Kwiatkowski, J. (2017). Greedy state? The effect of the government shareholder on the dividend payout ratio and smoothing. International Journal of Contemporary Management, 16(4). doi:10.4467/24498939IJCM.17.041.8264.

Schooley, D.K., \& Barney, L.D. (1994). Using dividend policy and managerial ownership to reduce agency costs. Journal of Financial Research, 17(3). doi:10.1111/j.1475-6803.1994.tb00198.x.

Short, H., Zhang, H., \& Keasey, K. (2002). The link between dividend policy and industrial ownership. Journal of Corporate Finance, 8(2). doi:10.1016/ s0929-1199(01)00030-x. 
Sierpińska-Sawicz, A. (2014). Dividend policy of state treasury shareholding companies. Journal of Economics and Management, 18.

Smith, D.D., Pennathur, A.K., \& Marciniak, M.R. (2017). Why do CEOs agree to the discipline of dividends? International Review of Financial Analysis, 52. doi:10.1016/j.irfa.2017.04.010.

Stanisz, A. (2007). Przystępny kurs statystyki, tom 2. Kraków: StatSoft.

Wellalage, N.H., Fouzi, F., Wang, A., \& Basyith, A. (2014). Corporate governance and cash dividend policy: evidence from Chinese IPOs. Malaysian Accounting Review, 13(1).

\section{Acknowledgements}

Author contributions: author has given an approval to the final version of the article.

Funding: this research was undertaken as part of the Financial determinants and results of pay-out policy of industrial companies listed on the WSE project and was fully funded by a grant (B1711200001666.02).

Note: the results of this study were presented at Second Scientific Conference Institutions: theory and practice (June, 19-20 2018, Torun, Poland). 


\section{Appendix}

\section{Table 1.}

\section{Characteristics of the research variables}

\begin{tabular}{|c|c|}
\hline Variable & Description \\
\hline div & binary variable equal to 1 if the company is a dividend payer in year $t$, otherwise equal to 0 \\
\hline$d p r$ & $\begin{array}{l}\text { dividend pay-out ratio in year } t \text { (calculated as a relationship between dividend per share and earn- } \\
\text { ings per share) }\end{array}$ \\
\hline institution & share of votes of institutional investors in the total number of votes in year $t-1$ \\
\hline individual & $\begin{array}{l}\text { share of votes of individual investors holding at least } 5 \% \text { of votes in the total number of votes in year } \\
t-1\end{array}$ \\
\hline company & $\begin{array}{l}\text { share of votes of legal persons (excluding institutional investors) in the total number of votes in year } \\
t-1\end{array}$ \\
\hline state & share of votes of State Treasury in the total number of votes in year $t-1$ \\
\hline ffloat & $\begin{array}{l}\text { share of votes of free float (investors holding lower than } 5 \% \text { of all shares) in the total number of votes } \\
\text { in year } t-1\end{array}$ \\
\hline board_size & total number of board members in year $t-1$ \\
\hline board_dual & $\begin{array}{l}\text { binary variable equal to } 1 \text { if at least one of board members is a shareholder in year } t-1 \text {, otherwise } \\
\text { equal to } 0\end{array}$ \\
\hline board_votes & share of votes of board members in the total number of votes in year $t-1$ \\
\hline board_indep & ratio showing the percentage of board members without shares in year $t-1$ \\
\hline chairm_year & number of years of the chairman in this position \\
\hline profit & return on assets ratio in year $t-1$ calculated as a relation between net profit and total assets \\
\hline liquid & current ratio in year $t-1$ calculated as relationship between current assets and current liabilities \\
\hline ln_size & size of the company in year $t-1$ measured by natural logarithm of total assets \\
\hline tobin_q & $\begin{array}{l}\text { ratio describing the growth opportunities defined as a relationship between the sum of market } \\
\text { capitalization and debts to total assets }\end{array}$ \\
\hline
\end{tabular}

Source: Own preparation.

\section{Table 2.}

\section{Characteristics of the research sample}

\begin{tabular}{lcccc}
\hline \multirow{2}{*}{ Specification } & \multicolumn{2}{c}{ Shareholders } & \multicolumn{2}{c}{ Dominant shareholders } \\
\cline { 2 - 5 } & Number & Share & Number & Share \\
\hline individual investors & 195 & 0.551 & 116 & 0.328 \\
institutional investors & 192 & 0.542 & 45 & 0.127 \\
companies & 66 & 0.186 & 108 & 0.305 \\
State Treasury & 18 & 0.051 & 14 & 0.039 \\
free float & 354 & 1.000 & 71 & 0.205 \\
all investors & - & - & 354 & 1.000 \\
\hline
\end{tabular}

Source: Own preparation based on data collected from the Notoria Serwis database. 
Table 3.

Descriptive statistics and t-statistic for two independent groups

\begin{tabular}{lrcccrr}
\hline \multirow{2}{*}{ Variables } & \multicolumn{2}{c}{ Dividend payers } & \multicolumn{2}{c}{ Dividend non-payers } & \multicolumn{2}{c}{ Mean difference } \\
\cline { 2 - 6 } institution & Mean & Standard deviation & Mean & Standard deviation & t-statistic & p-value \\
individual & 0.151 & 0.152 & 0.091 & 0.135 & -3.862 & 0.000 \\
company & 0.250 & 0.279 & 0.226 & 0.276 & -0.792 & 0.429 \\
state & 0.039 & 0.250 & 0.208 & 0.271 & 1.034 & 0.302 \\
ffloat & 0.309 & 0.147 & 0.012 & 0.070 & -2.317 & 0.021 \\
board_size & 3.472 & 1.511 & 0.375 & 0.254 & 2.538 & 0.012 \\
board_dual & 0.362 & 0.483 & 2.863 & 1.746 & -3.300 & 0.001 \\
board_votes & 0.113 & 0.182 & 0.251 & 0.435 & -2.217 & 0.027 \\
board_indep & 0.824 & 0.281 & 0.080 & 0.167 & -1.704 & 0.089 \\
chairm_year & 6.135 & 5.778 & 4.443 & 0.339 & -0.615 & 0.539 \\
profit & 0.072 & 0.051 & 0.047 & 0.018 & -2.087 & 0.038 \\
liquid & 2.340 & 2.197 & 1.749 & 2.497 & -4.934 & 0.000 \\
ln_size & 12.861 & 1.428 & 12.224 & 1.279 & -2.228 & 0.026 \\
tobin_q & 1.391 & 0.836 & 1.234 & 0.866 & -4.304 & 0.000 \\
\hline$N$ & & 127 & & 227 & -1.658 & 0.098 \\
\hline
\end{tabular}

Source: Own preparation based on data collected from the Notoria Serwis database. 


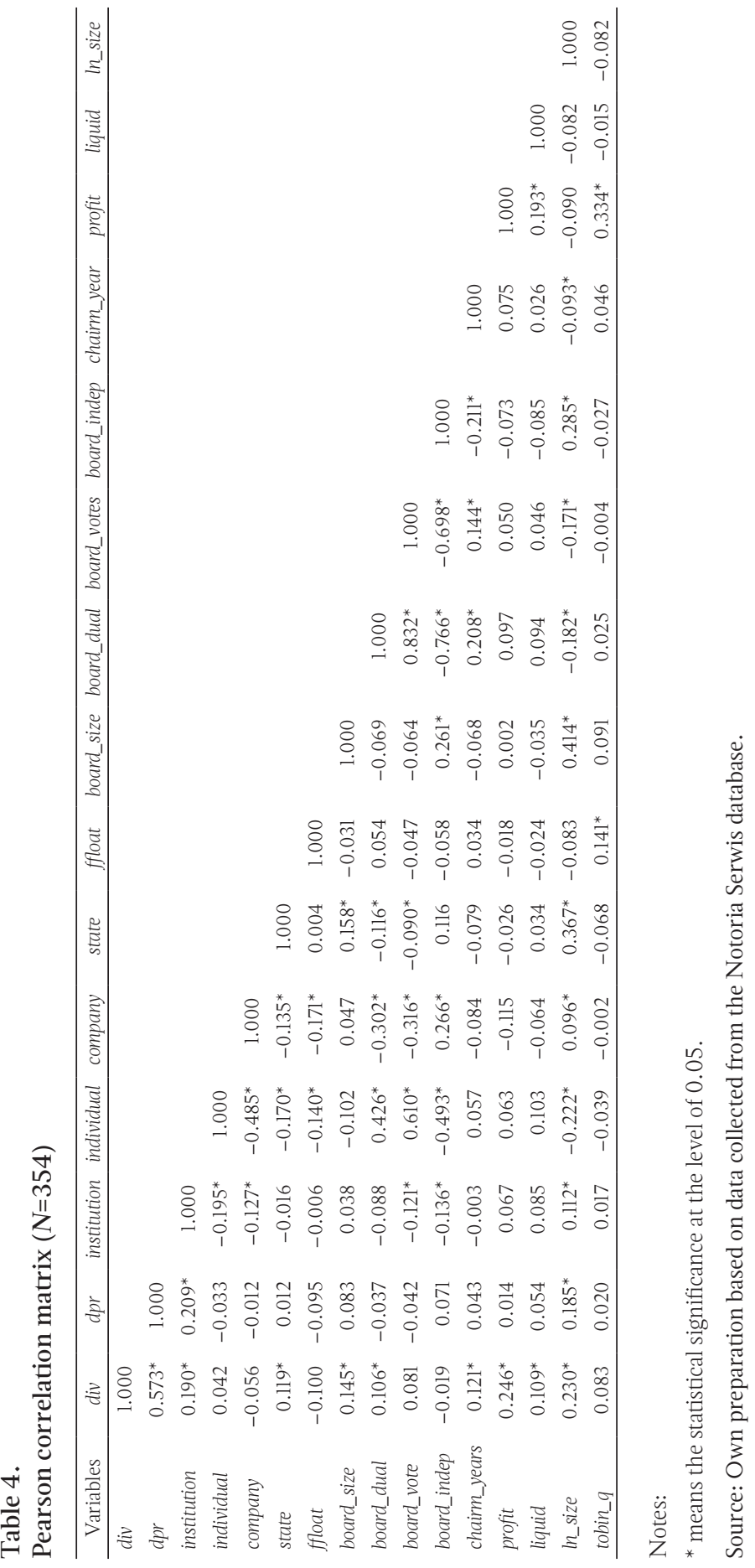


Table 5.

Estimation results of logistic regression model $(N=354)$

\begin{tabular}{|c|c|c|c|c|c|c|}
\hline \multirow{2}{*}{ Variables } & \multicolumn{3}{|c|}{ Model } & \multicolumn{3}{|c|}{ Final model } \\
\hline & $\beta$ & t-statistic & $\mathrm{p}$-value & $\beta$ & t-statistic & $\mathrm{p}$-value \\
\hline institution & 3.147 & 3.396 & 0.001 & 2.774 & 3.326 & 0.001 \\
\hline individual & 0.722 & 1.088 & 0.277 & - & - & - \\
\hline company & 0.523 & 0.830 & 0.407 & - & - & - \\
\hline state & 1.708 & 1.319 & 0.188 & - & - & - \\
\hline ffloat & -1.127 & -1.705 & 0.089 & -1.325 & -2.207 & 0.028 \\
\hline board_size & 0.092 & 1.081 & 0.280 & - & - & - \\
\hline board_dual & 0.628 & 1.918 & 0.056 & 0.753 & 2.642 & 0.009 \\
\hline chairm_year & 0.035 & 2.017 & 0.044 & 0.033 & 1.826 & 0.069 \\
\hline profit & 11.096 & 3.903 & 0.000 & 12.051 & 4.584 & 0.000 \\
\hline liquid & 0.058 & 1.128 & 0.260 & - & - & - \\
\hline ln_size & 0.398 & 3.537 & 0.000 & 0.471 & 4.827 & 0.000 \\
\hline tobin_q & 0.071 & 0.437 & 0.662 & - & - & - \\
\hline intercept & -7.434 & -4.962 & 0.000 & 7.500 & -5.641 & 0.000 \\
\hline Wald $\mathrm{Chi}^{2}$ & & 79.853 & & & 74.395 & \\
\hline p-value & & 0.000 & & & 0.000 & \\
\hline
\end{tabular}

Source: Own preparation based on data collected from the Notoria Serwis database using Statistica.

Table 6.

Estimation results of Tobit regression model $(N=354)$

\begin{tabular}{lcccrrr}
\hline \multirow{2}{*}{ Variables } & \multicolumn{5}{c}{ Model } & \multicolumn{3}{c}{ Final model } \\
\cline { 2 - 6 } & \multicolumn{1}{c}{$\beta$} & z-statistic & p-value & $\beta$ & z-statistic & p-value \\
\hline institution & 2.675 & 3.883 & 0.000 & 2.582 & 4.054 & 0.000 \\
individual & 0.371 & 0.742 & 0.457 & - & - & - \\
company & 0.145 & 0.307 & 0.758 & - & - & - \\
state & 0.233 & 0.260 & 0.794 & - & - & - \\
ffloat & -1.049 & -2.162 & 0.031 & -1.167 & -2.576 & 0.010 \\
board_size & 0.041 & 0.632 & 0.527 & - & - & - \\
board_dual & 0.256 & 1.049 & 0.294 & 0.362 & 1.703 & 0.088 \\
chairm_year & 0.022 & 1.824 & 0.068 & 0.021 & 1.758 & 0.078 \\
profit & 4.463 & 2.098 & 0.035 & 5.256 & 2.713 & 0.007 \\
liquid & 0.053 & 1.349 & 0.177 & - & - & - \\
In_size & 0.309 & 3.663 & 0.000 & 0.322 & 4.473 & 0.000 \\
tobin_q & 0.052 & 0.437 & 0.662 & - & - & - \\
intercept & -5.361 & -4.779 & 0.000 & -5.110 & -5.149 & 0.000 \\
\hline WaldChi2 & & 48.709 & & & 46.748 & 0.000 \\
p-value & & 0.000 & & & & \\
\hline
\end{tabular}

Source: Own preparation based on data collected from the Notoria Serwis database using Gretl. 